Buana Sains Vol 19 No 2 : 41 - 46, 2019

\title{
FORMULASI GULA AREN DAN JAHE PADA PERMEN LEATHER MENGKUDU SEBAGAI PANGAN FUNGSIONAL
}

\author{
Rika Diananing Putri ${ }^{1}$, Aryo Wibisono ${ }^{2}$, Dody Tri Kurniawan ${ }^{3}$ \\ ${ }^{1}$ Prodi. Teknologi Hasil Pertanian Fakultas Pertanian Universitas Wiraraja \\ ${ }^{2}$ Prodi. Manajemen Fakultas Ekonomi dan Bisnis Universitas Wiraraja \\ ${ }^{3}$ Prodi. Agribisnis Fakultas Pertanian Universitas Wiraraja
}

\begin{abstract}
Functional food is a nutrient that is needed by the body, besides the basic components contained in food. Supporting local resources such as spices, tuber crops, vegetables, fruit and so on. Noni is one of the potentials of local plants that are classified in functional food. Noni fruit is rarely liked because of the pungent aroma. With a touch of food engineering technology, the noni fruit can be used as a processed product in the form of snacks that contain nutrients for the body. This supports the research in making noni fruit products into leather candy that can be liked by the public. Noni leather candy formulation with the addition of palm sugar and ginger in a sequence of $25 \%, 35 \%$ and $10 \%, 20 \%, 35 \%$. Stages of research using organoleptic (hedonic) tests on the taste, color, aroma, and texture of noni leather candy, using the two-way ANOVA Complete Randomized Design (RAL) method and continued with the Duncan's Method Range Test (DMRT). Panelists included 40 semi-trained, 60 nontrained. The resulting average in color is 3.82; taste 4,6; aroma of 3.58; texture 3.82 . Based on these results, the dominant formulation preferred by panelists is A2J3 (35\% palm sugar; $30 \%$ ginger) followed by laboratory testing which includes water content using a gravimetry / oven method, the result is $20.82 \%$, ash content using a gravimetry method / furnace the result $3.99 \%$, protein content using the Kjeldahl method /tool with a yield of $4.54 \%$, fat content using the Soxhlet method with a yield of $0.07 \%$, carbohydrate content using the method / tool by difference with a yield of $70.58 \%$, antioxidant activity using DPPH produces $38.35 \mathrm{Meg} / 100 \mathrm{gr}$ and vitamin C content using the LOD titration method resulted in $225.7 \%$.
\end{abstract}

Keywords: Candy leather; functional food; ginger; sugar aren; noni.

\section{Pendahuluan}

Dewasa ini pangan fungsional merupakan pangan yang memiliki kandungan nutrisi yang dibutuhkan tubuh selain komponen gizi yang dikandung pada suatu bahan pangan. Pemahaman tersebut dengan memanfaatkan potensi lokal seperti rempah, tanaman umbi, buah, sayur serta berbagai komoditi pertanian yang dijadikan sebagai sumber pangan. Potensi lokal yang dimiliki seperti tanaman mengkudu yang memiliki banyak manfaat bagi kesehatan seperti pada buah yang pemanfaatannya dapat meningkatkan sistem imun, menurunkan kolesterol, mengurangi stress, menurunkan resiko encok/asam urat dan sebagainya. Pengembangan buah mengkudu sebagai pangan fungsional masih terhalang oleh minat masyarakat terhadap konsumsi buah mengkudu. Minat terhadap konsumsi buah mengkudu sangat minim, sebagian besar yang mengkonsumsi 
R. D. Putri, A. Wibisono dan D. T. Kurniawan/ Buana Sains Vol 19 No 2 : 41-46

masyarakat pada usia lanjut. Mutu mengkudu terbagi tiga yaitu berdasarkan pada fisik buah mengkudu. Kandungan buah mengkudu, menurut (Islamiah, 2019) senyawa yang terkandung yaitu kadar air 89,10\%, kadar abu 1,20\%, protein $2,90 \%$, lemak $0,60 \%$, karbohidrat $2,20 \%$, serat $3 \%$, sedangkan untuk kesehatan buah mengkudu berkhasiat meningkatkan daya tahan tubuh, pemulihan sel-sel tubuh, menurunkan tekanan darah, menstabilkan gula darah, anti kankern anti radang dansebagainya. Berdasarkan hal tersebut, maka dengan teknologi rekayasa pangan, mengolah menjadi kudapan dengan bahan dasar buah mengkudu untuk disuka oleh semua usia. Pembuatan fruitleather salah satu cara untuk meningkatkan minat terhadap buah mengkudu.

Fruitleather salah satu olahan dengan bentuk permen/manisan berupa lembaran dengan ketebalan 2-3mm yang kadar air sekitar 20-25\% b/b. Olahan fruitleather masih terasa asing karena belum diaplikasikan di Indonesia, tetapi sudah banyak penelitian tentang produk leather seperti (Marzelly, 2017) menggunakan pisang ambon sebagai bahan baku, (Winarti, 2008) mengkudu dengan penambahan kelopak rosella untuk menunjang pada uji organoleptik leather.

Tujuan penelitian ini untuk mendapatkan formulasi gula aren dan jahe pada pembuatan produk leather mengkudu.

\section{Metode Penelitian}

Metode yang digunakan adalah metode eksperimen dan olah data dengan Rancangan Acak Lengkap (RAL) dengan pola faktor $2 \times 3$ yaitu gula aren $(25 \%$, $35 \%)$ dan jahe $(10 \%, 20 \%, 30 \%)$. Pengumpulan data uji organoleptik dilakukan terhadap 100 panelis yang terdiri dari 60 panelis tidak terlatih dan 40 orang panelis semi terlatih. Data yang dihasilkan dari uji organoleptik yang meliputi rasa, aroma, warna dan tekstur dengan skala kesukaan (uji hedonik) yaitu 1 (sangat tidak suka), 2(tidak suka), 3(biasa), 4(suka), 5(sangat suka). Hasil uji organoleptik dianalisa menggunakan statistik metode anova ganda (two way anova). Data yang dihasilkan berpengaruh terhadapp produk, maka dilanjut menggunakan Duncan's Multiple Range Test (DMRT). Produk terbaik dari uji organoleptik dilakukan uji laboratorium (kandungan air, kadar abu, kandungan protein, kandungan lemak, kandungan karboidrat).

\section{Bahan dan alat}

Bahan yang digunakan yaitu Mengkudu (kondisi ranum, segar), gula aren lokal, jahe lokal (khas Kab. Sumenep), Karagenan, Asam Sitrat. Alat yang digunakan untuk membuat produk permen leather mengkudu yaitu oven, blender, wadah stenless stell, pisau, tatakan irisan, dandang, kompor, kertas roti, silpat.

\section{Pelaksanaan Penelitian}

\section{Pembuatan Permen Leather Mengkudu}

Buah mengkudu masak pohon/ranum berwarna putih bersih, ditimbang sebanyak 500gr, dan dicuci bersih pada air mengalir. Blancing seelama 15 menit. Potong buah mengkudu ukuran $1 \mathrm{~cm}$ untuk memudahkan penghancuran menjadi bubur mengkudu. Penghancuran buah mengkudu selama 15 menit hingga halus. Tambahkan gula aren, jahe, karagenan dan asam sitrat sesuai dengan formulasi. Bubur mengkudu siap untuk dioven dengan ketebalan 2-3 mm. Oven selama 24 jam pada suhu 50 derajat celcius seperti pada gambar 1 . 
R. D. Putri, A. Wibisono dan D. T. Kurniawan/ Buana Sains Vol 19 No $2: 41-46$

\section{Hasil Dan Pembahasan}

\section{Uji Organoleptik Pada Permen Leather Mengkudu} 2 berikut.

Uji organoleptik pada permen leather mengkudu menghasilkan rerata pada tabel

Tabel 1. Rerata Uji Organoleptik Permen Leather Mengkudu

\begin{tabular}{cccccc}
\hline \multirow{2}{*}{ No } & \multirow{2}{*}{ Formulasi } & \multicolumn{4}{c}{ Parameter } \\
\cline { 3 - 6 } & A1J1 & Rasa & Aroma & Warna & Tekstur \\
\hline 1 & A1J2 & 2,69 & 1,59 & 1,77 & 2,51 \\
2 & A1J3 & 2,77 & 2,06 & 1,42 & 2,66 \\
3 & A2J1 & 3,00 & 2,74 & 2,08 & 2,74 \\
4 & A2J2 & 3,45 & 2,64 & 2,44 & 2,70 \\
5 & A2J3 & 4,60 & 3,58 & 3,44 & 3,17 \\
6 & & & & & 3,82 \\
\hline
\end{tabular}

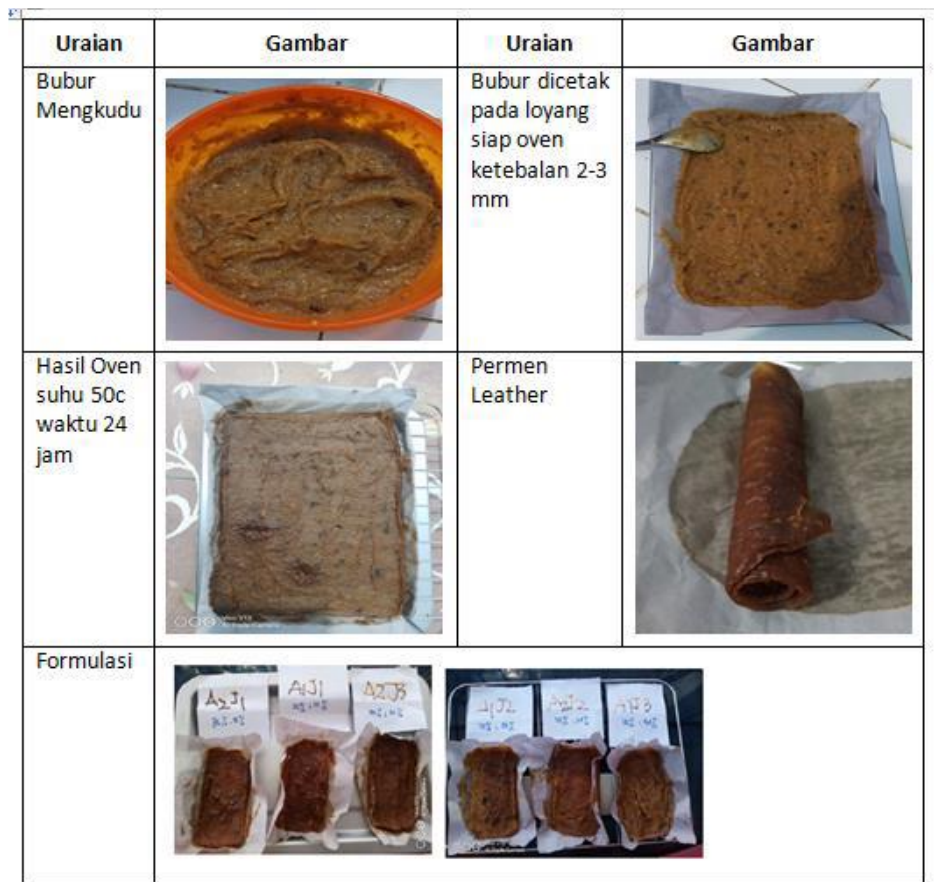

Gambar 1. Proses pembuatan permen leather mengkudu dengan penambahan jahe dan gula aren

Berdasarkan tabel 1 rerata yang dihasilkan pada masing masing parameter, terdapat nilai tertinggi, yaitu pada rasa dengan skor tertinggi pada formulasi A2J3 sebesar 4,60. Penerimaan panelis terhadap rasa memperlihatkan semakin banyak rosentase gula aren dan jahe yang ditambahkan mendekati sangat suka, karena rasa yang dihasilkan manis, sedikit pedas dan ada rasa asam. Menurut (Lawalata, 2015) menjelaskan semakin meningkat penggunaan gula maka akan berpengaruh terhadap rasa penerimaan panelis. Aroma merupakan salah satu yang berpengaruh terhadap makanan. Dari segi aroma permen leather mengkudu menunjukkan tingkat kesukaan panelis (mendekati suka. 
R. D. Putri, A. Wibisono dan D. T. Kurniawan/ Buana Sains Vol 19 No 2 : 41-46

Aroma yang dihasilkan permen leather mengkudu dapat diterima oleh panelis. Warna yang dihasilkan terhadap kesukaan panelis yaitu mendekati suka pada formulasi A2J3 (35\%,30\%). Jadi penambahan tersebut berpengaruh terhadap daya kesukaan panelis. Dalam (Jumri, 2015) bahwa lingkungan atau tempat uji sensori berpengaruh seperti pengaruh lampu/cahaya, ukuran dan bentuk sampel, sehingga mempengaruhi penampilan secara visual dari produk leather mengkudu yang disajikan.

Warna menurut (Faradina, 2018) panelis menyukai warna terang pada produk leather. Sedangkan penelitian (Pontoh, 2014) menjelaskan warna pada gula aren dengan spektofotometer memiliki panjang gelombang 420-720nm. Kualitas gula aren disebutkan oleh (Ririnsia, Hau, Aji, Hau, \& Talu, 2016) berasal dari kualitas nira yang digunakan dan lama dan suhu pemasakan. (Utami, 2008) Gula merah salah satu peluang usaha dan (Ariadianti, 2015) Penambahan gula pada produk leather berpengaruh terhadap karakteristik. Warna dan tekstur disuka panelis pada nilai 3,82 dengan kategori panelis suka, karena warna akan yang menentukan dan dapat mempengaruhi konsumen. Rasa permen leather dengan kesukaan panelis menghasilkan nilai tertinggi sebesar 4,60. Hal ini disebabkan rasa yang ada pada permen leather mengkudu dapat diterima konsumen dalam kategori suka hingga sangat suka. Hal ini disebabkan adanya penambahan jahe dan gula aren dengan konsentarasi $35 \%$ untuk gula aren sehingga memberikan rasa khas gula aren dan jahe $30 \%$ memberikan rasa pedas yang disuka panelis. Rasa merupakan faktor yang berpengaruh terhadap penerimaan konsumen dalam menerima atau menolak produk pangan.

Tekstur permen leather disuka oleh panelis, dengan nilai 3,82. Hal ini disebabkan karena tekstur yang dihasilkan lentur. Hal ini disebabkan adanya penambahan karagenan sehingga menghasilkan produk permen leather yg lentur.

\section{Uji Kimia Pada Permen Leather Mengkudu}

Uji kimia dilakukan di Laboratorium Pengujian Terpadu Universitas Pembangunan Nasional Veteran Jatim. Tujuan dilakukan untuk mengetahui kandungan zat gizi yang meliputi kandungan air, protein, lemak, karbohidrat. Setelah diketahui hasil uji organoleptik pada rasa, aroma, warna dan tekstur, dilakukan uji kimia.

Kandungan air menurut hasil uji menggunakan metode gravimetri/oven sebesar 20,82\%. Kadar air pada suatu bahan pangan mempengaruhi terhadap mutu produk tersebut. Seperti pada produk leather mengkudu, yang memiliki kadar air mendekati $21 \%$, menurut (Ariadianti, 2015) kandungan air dapat berpengaruh terhadap lama penyimpanan produk. Menurut (Marzelly, 2017) penambahan gula berpengaruh terhadap kandungan air produk karena memungkinkan dengan semakin banyak gula yang ditambahkan maka semakin tinggi kandungan air pada suatu produk yang akan berpengaruh terhadap umur simpan. Kadar air dalam 100gr mengkudu sebesar 89,10\%, hal ini dengan pengolahan mengkudu menjadi permen leather adanya penguapan pada oven. Kadar air mengalami pengurangan karena penguapan, seperti yang dikemukakan oleh (Sudirman, 2018) dalam penelitiannya menjelaskan penurunan kadar air secara simultan dipengaruhi oleh ketebalan bahan pangan yang akan di keringkan.

Kadar abu dianalisa menggunakan metode Furnace hasilnya $3.99 \%$. Kadar protein dianalisa 
R. D. Putri, A. Wibisono dan D. T. Kurniawan/ Buana Sains Vol 19 No 2 : 41-46

menggunakan metode/alat Kjedahl dengan hasil 4,54\%. Terjadi peningkatan dari kadar protein buah mengkudu yang awalnya $2,90 \%$ menjadi $4,54 \%$, kemungkinan disebabkan adanya penambahan gula aren dan jahe sehingga kandungan protein terjadi peningkatan. Kadar lemak menggunakan metode Soxhlet dengan hasil 0,07\%. Lemak yang terkandung pada buah mengkudu segar sebesar $0,60 \%$, dan terjadi penurunan pada produk leather yang dihasilkan. Produk leather dengan rendah lemak dapat dikonsumsi oleh masyarakat, dan aman untuk penderita kolesterol. Kadar karbohidrat dianalisa menggunakan metode/alat by defference dengan hasil $70.58 \%$. Penambahan gula aren akan memicu tingginya kandungan karbohidrat. Aktivitas antioksidan menggunakan DPPH menghasilkan $38.35 \mathrm{Meg} / 100 \mathrm{gr}$ dan kandungan vitamin $\mathrm{C}$ menggunakan metode titrasi LOD menghasilkan $225.7 \%$. Hal ini pada aktivitas antioksidan sangat berperan dalam mutu suatu produk. Penambahan jahe dan digabungkan dengan buah mengkudu akan menghasilkan antioksidan yang tinggi. Jahe dan buah mengkudu memiliki kemampuan antioksidan sangat berperan sehingga dapat meningkatkan kandungan aktivitas antioksidan. Buah mengkudu memiliki komponen bioaktif seperti flafonoid, triterpen, triterpenoid, dan saponin dalam jumlah yang signifikan. Sedangkan ppada jahe memiliki kandungan bioaktif yang memiliki aktivitas antioksidan melebihi tokoferol. Semakin tinggi konsentrasi mengkudu dan jahe, maka semakin tinggi pula aktivitas antioksidan (Islamiah, 2019). Uji kimia pada permen leather mengkudu mengalami peningkatan, kemungkinan disebabkan karena adanya penambahan gula aren dan jahe yang dapat meningkatkan prosentrase.

\section{Kesimpulan}

Dari penelitian ini dapat disimpulkan bahwa:

1 Hasil uji organoleptik permen leather mengkudu, panelis suka terhadap penambahan gula aren dan Jahe dengan konsentrasi 35\% dan 30\%. Rerata yang dihasilkan yaitu pada Rasa $(4,60)$, Aroma $(3,58)$, Warna $(3,82)$ dan tekstur (3,82), Hal tersebut menunjukkan adanya pengaruh yang nyata pada permen leather mengkudu.

2 Dari produk terbaik uji organoleptik, memiliki kandungan air sebesar $20.82 \%$, Kandungan abu 3,99\%; Kandungan protein 4,54\%; kandungan lemak 0,07, kandungan karbohidrat 70,58\%, Vitamin C 225,7\% dan Aktivitas Antioksidan $38,35 \mathrm{Meg} / 100 \mathrm{gr}$.

\section{Ucapan Terima Kasih}

Direktorat Riset dan Pengabdian Masyarakat (DRPM) Kementrian Ristek Dikti yang telah mendanai penelitian ini melalui Program Penelitian Dosen Pemula.

\section{Daftar Pustaka}

Ariadianti. (2015). Formulasi Dan Penentuan Umur Simpan Fruit Leather Mangga (Manginefera Indica L.) Dengan Penambahan Kulit Buah Naga Merah (Hylocereus Polyrhizus) Menggunakan Metode Accelerated Shelf Life Testing Model Arrhenius. Ariadianti, 16(3), 179-194.

Faradina. (2018). Studi Pembuatan Fruit Leather Pisang Kepok Merah ( Kajian Konsentrasi Karagenan Dan Sukrosa ) The Study Of Making Fruit Leather Red Kepok Banana ( Studies Concentration Of Carrageenan And Sucrose ). Jurnal 
Pangan Dan Agroindustri Vol.6 No.4: 49-58, Oktober 2018, 6(4), 49-58.

Fauziah, Et All. (2015). Kajian Karakteristik Sensoris Dan Fisikokimia Fruit Leather Pisang Tanduk ( Musa Corniculata ) Dengan Penambahan Berbagai Konsentrasi Karagenan. Jurnal Aplikasi Teknologi Pangan 4 (1) 2015. Indonesian Food Technologists, 4(1), 11-16.

Hesti Heryani. (2016). Keutaamaan Gula Aren Dan Strategi Pengembangan Produk (Cetakan Pe). Lambung Mangkurat University Press.

Islamiah. (2019). Analisis Mutu Minuman Instan Berbahan Dasar Buah Mengkudu (Morinda Citrifolia) Dan Jahe Merah (Zingiber Officinale Cole). Jurnal Pendidikan Teknologi Pertanian, 5, 8-20.

Jumri. (2015). Mutu Permen Jelli Buah Naga Merah (Hylocereus Polyrhizus) Dengan Penambahan Karagenan Dan Gum Arab. Jom

Lawalata. (2015). Mutu Organolepptik Fruitleather Gandaria. Jurnal Agroforestri X Nomor 2 Juni 2015, 73.

Marzelly, Et All. (2017). Karakteristik Fisik, Kimia, Dan Sensoris Fruit Leather Pisang Ambon (Musa Paradisiaca S.) Dengan Penambahan Gula Dan Karagenan. Jurnal Agroteknologi, 11(2).

Permatasari. (2017). Karakteristik Fisik, Kimia Dan Organoleptik Vegetable Leather Cabai Hijau (Capsicum Annuum Var. Annuum) Dengan Penambahan Berbagai Konsentrasi Pektin. Jurnal Teknologi Hasil Pertanian, X(1), 21-31.
Pontoh, J. (2014). Pengembangan Metode Analisa Warna Gula Aren. Artikel, 2012-2015.

R Sudirman. (2018). Pengaruh Pengeringan Menggunakan Room Dryer Terhadap Kualitas Tepung Sagu. Jurnal Pendidikan Teknologi Pertanian Volume 4 September Suplemen (2018): S104-S112, 4(PIssn: 2476-8995 E-Issn: 2614 7858), 104-112.

Swardani, H. (2015). Pengaruh Jumlah Gula Dan Ubi Jalar Ungu Terhadap Hasil Jadi Permen Leather Sirsak. E-Journal Boga, 4, 18-27.

Utami. (2008). Studi Pengembangan Usaha Gula Merah Tebu Di Kabupaten Rembang (Studi Kasus Di Kecamatan Amotan, Kabuppaten Rembang). Karya Ilmiah, 1-128.

Winarti, S. (2008). Pemanfaatan Buah Mengkudu (Morinda Citrifolia) Dan Kelopak Bunga Rosela ( Hibiscus Sabdariffa Linn ) Untuk Pembuatan Fruit Leather. Agritech, 28(1), 22-27. 